\title{
THE PSYCHOLOGICAL EFFECT OF ELECTORAL SYSTEMS IN \\ FOUNDING ELECTIONS*
}

\author{
Ignacio Lago \\ Universitat Pompeu Fabra \\ Department of Political and Social Sciences \\ Ramon Trias Fargas 25-27 \\ 08005 Barcelona, Spain \\ ignacio.lago@upf.edu
}

\begin{abstract}
In this research note I revisit the conventional wisdom about when the psychological effect of electoral systems is observed. I rely on data from the first presidential and legislative elections in 45 third- and fourth-wave presidential and semipresidential regimes to show that the psychological effect of electoral systems manifests itself in the first election. The effective number of legislative parties is significantly higher than the effective number of presidential candidates in the first election when the electoral system in legislative elections is more permissive than in presidential elections.
\end{abstract}

Keywords: Coattails, electoral law, number of parties, psychological effect.

*I thank Marina Costa Lobo and Agustí Bosch for very helpful comments on a previous draft. I gratefully acknowledge the Salvador de Madariaga fellowship provided by the Ministerio de Educación, Cultura y Deportes of Spain for a research stay at the Instituto de Ciências Sociais da Universidade de Lisboa, where this paper was written; and the financial support from the Ministerio de Economía y Competitividad of Spain, research project CSO2013-40723-C2-1-R.

Ignacio Lago is Associate Professor of Political Science at Universitat Pompeu Fabra (Barcelona, Spain). His research interests include electoral systems, political behaviour and party politics. He has published in Public Opinion Quarterly, European Journal of Political Economy, European Journal of Political Research, Electoral Studies, Party Politics and Social Science Quarterly. His latest book is Multilevel Electoral Politics. Beyond the Second-Order Election Model (OUP). 
Since Duverger (1951), electoral system scholarship has established that electoral systems have mechanical and psychological effects. The former refer to their underrepresentation of small parties and the latter refer to the strategic behaviour of politicians and voters before the election: if the mechanical impact of the electoral system is anticipated, (some) non-viable parties may not run candidates or make alliances with other parties, while some voters will desert hopeless parties in favour of major parties (Blais and Carty, 1991; Blais et al., 2011). The interplay of the two effects reduces the number of parliamentary parties though the mechanical effect and the number of electoral parties through the psychological effect (Taagepera and Shugart, 1989: 65). In Rae's (1971) terminology, the mechanical effect is the proximal effect of electoral systems and the psychological effect is the distal one.

In this paper I revisit the conventional wisdom about when the psychological effect is observed. The basic insight is that the mechanical effect occurs during a single election but the psychological effect takes at least two elections to manifest itself (Taagepera and Shugart, 1989: 65). The tabula rasa perspective in Postcommunist countries, for instance, presents "an image of institutional experimentation that echoes the chaotic environment of the transition [and then] stresses the newness of the democratic experience and the propensity to form weak and fluid party configurations" (Bielasiak, 2002: 192 and 189). According to this perspective, political actors have no knowledge regarding the political landscape and the electoral strength of competitors in founding elections. Founding elections are dominated by a considerable uncertainty regarding three crucial variables of electoral democracies: the number of parties competing in the election; the vote shares of the different parties; and the consequences of the electoral rules. These dimensions are interdependent, in the sense that the 
uncertainty attached to any of them makes prediction of the others impossible (Andrews and Jackman, 2005: 67; Gallego et al., 2012). Tavits (2007: 116-7), for instance, argues that "when there is very little or no electoral history, ... it is not clear at the time of entry which parties will be viable on election day. Given such uncertainty, every potential entrant is perceived as having as good a chance of winning as any other, and voters can only vote sincerely." A less radical perspective, however, would argue that the psychological effect of electoral systems is not completely absent in founding elections. This effect is weaker in founding elections due to limited information, but information is never completely absent, especially in the third- and fourth-wave democracies, given the existence of opinion polls, news analyses, candidates statements (Cox, 1997: 78) or a previous democratic experience before the current democratic period (Lago and Martínez, 2012).

The empirical evidence about the psychological effect of electoral systems mainly comes from studies focused on times series modelling of election dynamics. As a result of a learning process about parties and candidates and their electoral prospects, the strategic behaviour of parties and voters increases over time after the founding election. Based on results from 2007 districts in 183 lower chamber elections across 21 countries, Crisp et al. (2012: 151-2) find evidence of a very steep learning curve: the first couple of elections show strong evidence of coordination issues, which subside quickly until the fifth election, when coordination becomes indistinguishable from that in more experienced settings. The duration of democracy is associated, for instance, with a significant decrease in the number of votes for non-viable candidates or the effective number of electoral parties (Best, 2010; Crisp et al., 2012; Duch and Palmer, 2002; Tavits and Annus, 2006; Tavits, 2007). 
Clearly, existing research strongly supports the developmental argument of the psychological effect: coordination increases over time after the founding election. However, from this empirical evidence it is not possible to infer whether political actors were behaving sincerely in the founding election or whether they were already behaving strategically. The existing research about electoral systems has been mostly silent about how important is the psychological effect in founding elections. In other words, there is robust empirical evidence showing that the slope of the psychological effect is positive (i.e., $\beta_{1}>0$ ), but the hypothesis that $\beta_{0}=0$ in the first election (i.e., a constant equal or almost equal to 0 and no strategic behaviour at all or scarce) is still an assumption which to the best of my knowledge has never been tested. The counterfactual that moving from a restrictive to a permissive electoral system does not make any difference to the behaviour of politicians and voters in the founding election is crying out for an empirical test. This is the gap filled by this research note.

\section{Empirical analysis}

First elections in third and fourth-wave presidential and semi-presidential regimes provide an ideal scenario to ascertain the timing of the psychological effect of electoral systems. Presidential elections are held under a majoritarian system, plurality or majority, while elections for the lower house can take place under a majoritarian, PR or mixed-member electoral system. Therefore, in some countries the carrying capacity of the presidential and the legislative electoral systems is similar, while in other countries (especially those using PR) the legislative electoral system is more permissive than the presidential one. ${ }^{1}$ If parties and voters do not respond to the different incentives

\footnotetext{
${ }^{1}$ Apart from the electoral formula and district magnitude, presidential and legislative elections differ in many other dimensions, e.g. the number of districts, the stake for holding office, criteria to be allowed to
} 
provided by electoral rules and do not behave strategically in the election, the effective number of electoral parties (enep) and the effective number of presidential candidates in the first round (enpres) should be similar even when the carrying capacity of the electoral systems is different. ${ }^{2}$ This is the null hypothesis. However, if the psychological effect manifests itself in the first election, enep should be greater than enpres when the carrying capacity of the legislative electoral system is greater than that of the presidential electoral system. This is the alternative hypothesis.

The sample of presidential and semi-presidential countries employed here includes 45 third- and fourth-wave democracies in which voters cast different votes for the presidency and the legislature (see the appendix for a description of the sample). Given that the psychological effect crucially depends on the availability of public and shared information, the focus on third- and fourth-wave democracies allows us to control for the role of the mass media. As Mainwaring and Zoco (2007: 167) argue, "in countries with weak democratic heritages, television became a mass phenomenon before parties were deeply entrenched in society. Candidates for executive office can get their messages across on television without the need to rely on well-developed party organizations.” Additionally, I select the first presidential and parliamentary election when the country becomes a democracy. If data about the number of parties and candidates in the first democratic parliamentary and presidential elections are not

run, individual candidates vs. party lists, or campaign funding conditions. However, the effect of these dimensions is not explored given that in general terms they are indistinguishable from the effect of the electoral formula and district magnitude.

${ }^{2}$ The effective number of electoral parties or presidential candidates is typically calculated as $1 / \sum v_{i}^{2}$, where $v_{i}$ is the percentage of votes won by the $i^{\text {th }}$ party or candidate. 
available, the country is dropped from the sample. A regime is classified as a democracy at the time of an election if (i) the chief executive is elected, (ii) the legislature is elected, (iii) there is more than one party competing in the elections, and (iv) an alternation under identical electoral rules has taken place (Cheibub et al., 2010). The source for all the data used in this article is Bormann and Golder (2013).

It can be argued that this research design is challenged by reverse causality and presidential coattails. First, it might be the case that countries that are more diverse (linguistically, culturally, or socially) tend to adopt more than others PR systems in legislative elections, which are supposedly more favorable to minority interests. However, this is not an issue for the empirical analysis. Given the limited or the lack of information about the carrying capacity of presidential and legislative in founding elections, diversity should equally affect the fragmentation of presidential and legislative party systems. Second, if coattails running from presidential to legislative elections already exist in founding elections, fragmentation in both elections should converge. However, coattails play in favor of the null hypothesis of no effect of electoral systems.

In the sample there are twenty presidential regimes, twenty-four semipresidential regimes and one parliamentary regime (Moldova) but where presidential elections are also held. Only in six countries the electoral formula used in the presidential election is plurality. The numbers of presidential candidates in the first presidential election in countries using plurality and majority are quite similar, 2.57 and 2.92 respectively. Not surprisingly given the low number of countries using plurality, the difference is not statistically significant $(t=0.60)$. In the legislative elections in the 
sample, nine countries use plurality, ten a mixed-member electoral system and twentysix PR.

The difference between enep and enpres in the sample of 45 countries is shown in Figure 1. As can be seen, there are substantial differences between enep and enpres in most of the countries and there are no big differences between countries with and without simultaneous presidential and legislative elections. There are three interesting results. First, the mean of enep is 4.42 and the mean of enpres is 2.86 . The (paired) difference is statistically significant at the 0.01 percent level $(t=4.49)$. Second, when we focus exclusively on the 15 countries with simultaneous presidential and legislative elections, the pattern is similar: the mean of enep is 4.23 , while the mean of enpres is 2.93. The (paired) difference is statistically significant at the 0.05 percent level $(\mathrm{t}=$ 2.89). Finally, in the 30 countries with non-simultaneous elections, the mean of enep is 4.52 and the mean of enpres is 2.82 . The (paired) difference is statistically significant at the 0.01 percent level $(t=3.57)$. In sum, the results clearly show that fragmentation is greater in the first legislative election than in the first presidential election and thus the null hypothesis of no coordination is rejected: the psychological effect already manifests itself in the first election. 
Figure 1: Comparing the effective number of electoral parties in legislative elections and the effective number of presidential candidates in forty-five countries

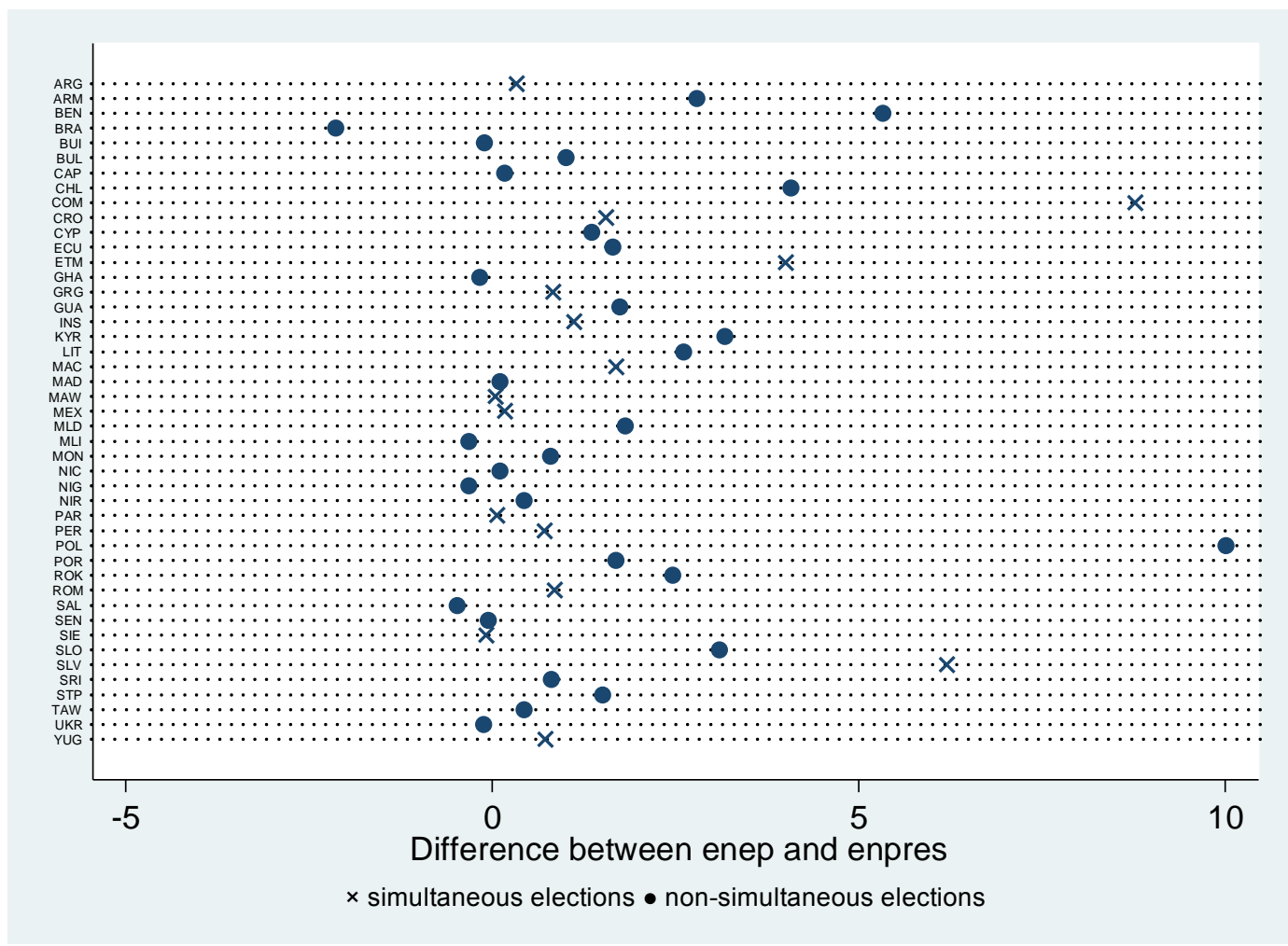

In Figure 2, I examine how the difference between enep and enpres varies across electoral systems in legislative elections. According to my argument, and given that the carrying capacity of all the presidential electoral systems in the sample of countries is largely similar, I expect that the difference between enep and enpres should increase the more permissive the electoral system in legislative elections is. Therefore, the greatest difference between enep and enpres should be observed in those countries using a PR system. As expected, countries using PR systems in legislative elections have a greater difference between enep and enpres (the median is 1.24 and the mean 1.87) than those using mixed-member (the median is 0.63 and the mean 1.13) and majoritarian systems (the median is 0.04 and the mean 1.17). The difference between enep and enpres is statistically significant at the $0.01(\mathrm{t}=3.84)$ and $0.05(\mathrm{t}=3.17)$ percent levels in those 
countries using PR and mixed-member electoral systems respectively, but not in those countries using a majoritarian electoral system $(\mathrm{t}=1.19)$.

Figure 2: Comparing the effective number of electoral parties in legislative elections and the effective number of presidential candidates across electoral systems

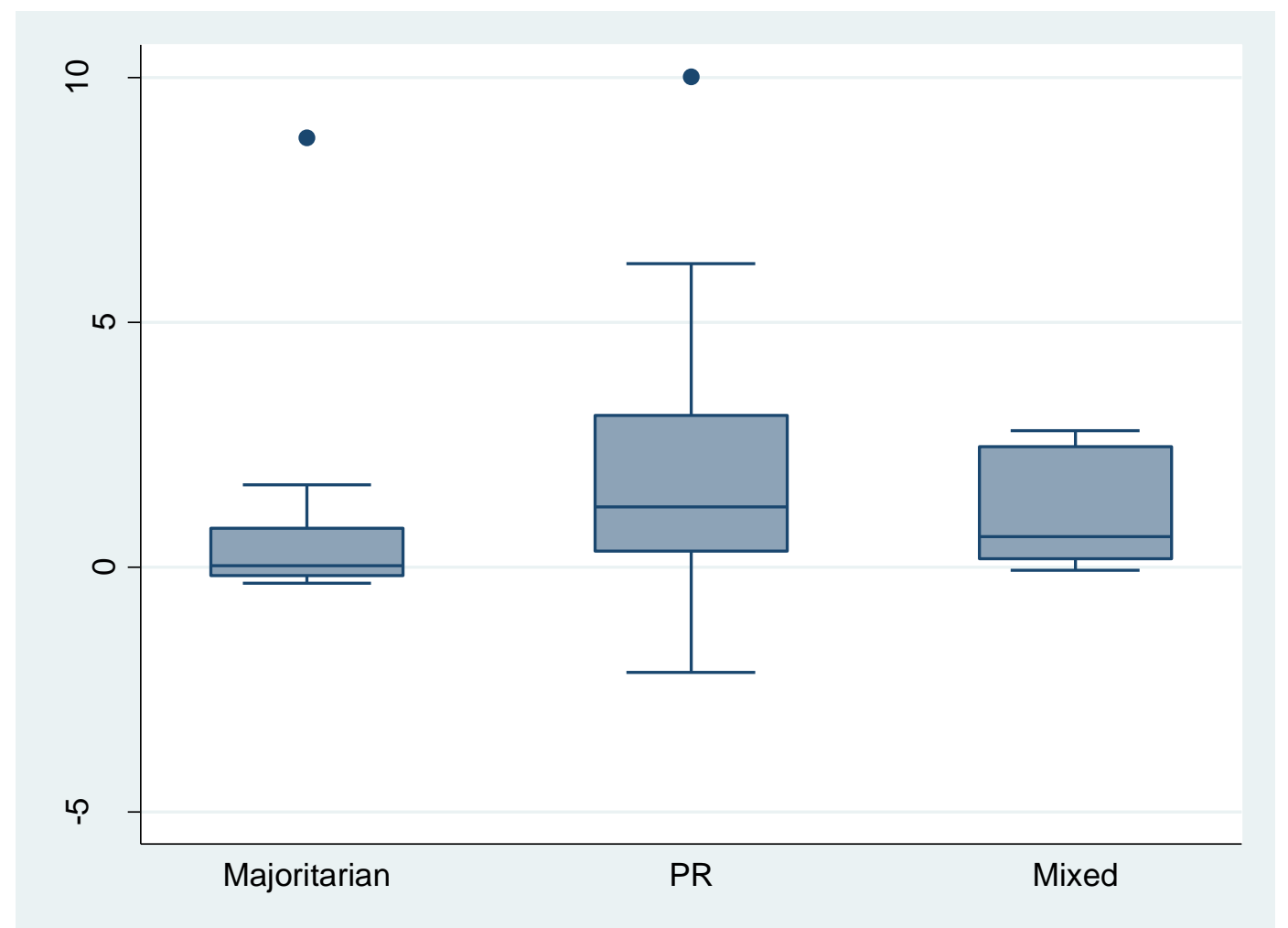

In Table 1 I estimate how the electoral system affects the difference between enep and enpres when controls for two standard institutional variables affecting the independence of presidential and legislative elections are added: the powers of the president and the temporal proximity between elections. ${ }^{3}$ According to existing research

\footnotetext{
${ }^{3}$ Using a dichotomous variable, I find no differences between countries depending on whether they have had a previous democratic experience before the current democratic period or not (Lago and Martínez, 2012). Similarly, when adding a dummy variable capturing the region (continent), the results do not change appreciably; only Asian countries significantly differ (at the 0.1 percent level) from the rest of the
} 
about coattails in presidential regimes (Golder, 2006; Hicken and Stoll, 2011; Stoll, 2015), the effect of presidential elections on legislative fragmentation increases the more powers the president has and when presidential elections are held in temporal proximity to legislative elections, no matter if presidential elections are held subsequent or prior to a legislative election. The two variables are defined as follows. First, as presidents in presidential regimes tend to have more powers than in semi-presidential ones, I create a dichotomous variable, presidential regime, which takes the value 1 if the regime is presidential and 0 if the regime is semi-presidential or parliamentary. Second, following Stoll (2015), the temporal proximity of legislative and presidential and legislative elections is measured as the logarithm of the absolute number of days between the dates of the first legislative and presidential elections plus one. A value of zero indicates that the elections are simultaneous. The greater the value, the less temporally proximate the presidential and the legislative elections are. In the sample of countries, the variable ranges from 0 in 15 countries to 7.65 in in Sri Lanka (the legislative election was held on February 151989 and the presidential on November 9 1994).

The key independent variable is the electoral system employed in the legislative election, Legislative electoral system. This is a categorical variable that takes one of three values indicting the basic type of electoral system used in the election: 1 , Majoritarian; 2, PR, 3, Mixed. The category of reference is majoritarian. Differences

sample. The results are available upon request. Given the relatively low number of degrees of freedom, these control variables have been not included in the estimates. 
between dependent and independent mixed electoral systems are not explored in this note as there are only ten countries using this type of electoral system. ${ }^{4}$

Apart from the difference between enep and enpres, I test the robustness of the results using two additional measures of the dependent variable. First, I use a relative measure of the dependent variable, the logarithm of (enep / enpres). When the enep / enpres is equal to 1, the fragmentation of presidential and legislative elections is similar; when the values of the ratio are greater than 1 , legislative elections are more fragmented than presidential elections, and the other way around when the values of the ratio are lower than 1 . The reason for using the logarithm is that when enep is greater than enpres, the ratio may vary between 1 and infinity. Hence, the resulting variable is highly skewed and the estimated effects are not additive. Second, enep is the dependent variable and enpres is included on the right side of the equation.

I run two models for each definition of the dependent variable: an additive model with the three independent variables and an interactive model in which an interaction term between Legislative electoral system and Number of days is added to the previous specification. ${ }^{5}$ The expectation is that the difference between enep and

\footnotetext{
${ }^{4}$ As I have found no differences in the effective number presidential candidates across electoral systems used in presidential elections, I do not control for the electoral formula used in the presidential election. However, the results do not change appreciably when a categorical variable indicating the electoral formula employed in the presidential election (1, plurality; 2 , majority or qualified majority; 3 , other formulas) is included in the models. The variable is not statistically significant. The results are available upon request.

${ }^{5}$ I have tested whether there is a significant interaction between legislative electoral system and presidential regime (i.e., the difference between enep and enep is greater in semi-presidential systems
} 
enpres when using a permissive legislative electoral system should increase the less temporally proximate presidential elections are to a legislative election. Estimation is by OLS. The models I estimate are as follows:

$Y_{i}=\beta_{0}+\beta_{1}$ Legislative electoral system $_{i}$

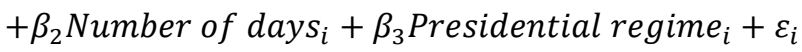

$Y_{i}=\beta_{0}+\beta_{1}$ Legislative electoral system $_{i}+$ $+\beta_{2}$ Number of days $_{i}+\beta_{3}$ Presidential regime $_{i}+\beta_{4}$ Legislative electoral system $\times \times$ Number of days ${ }_{i}+\varepsilon_{i}$

When the dependent variable is enep, enpres is added to the two models as independent variable.

It is immediately clear in Figures 1 and 2 that two observations, Comoros in the sample of countries using a majoritarian system in legislative elections and Poland in the sample of countries using a PR system in legislative elections, are outliers. Whereas the difference between enep and enpres is 8.77 for Comoros and 10.01 for Poland, it is only 1.20 (the standard deviation is 1.62) for the remaining forty-three. When running the models with the difference between enep and enpres as the dependent variable, the Studentized residual for Comoros is 3.26 and for Poland it is 3.33 , while all the residuals for the remaining observations do not exceed 1.93. Therefore, when the dependent variable is the difference between enep and enpres and enep, the models have

than in presidential ones), but the coefficients are far from being statistically significant. The results are available upon request. 
been estimated after dropping the observations from Comoros and Poland. There are no influential outliers when the dependent variable is the logarithm of (enep / enpres).

As expected, the three additive models show that in countries using PR and mixed-member systems in legislative elections, the difference between enep and enpres is greater than in countries using a majoritarian system. The dummy for PR systems is statistically significant at the 0.05 or 0.01 percent levels: in the first and fifth models, the effective number of electoral parties in legislative elections is about 1.3 greater in countries using PR than the effective number of presidential candidates; in the third model, the effective number of electoral parties in legislative elections is about 34 percent greater in countries using PR than the effective number of presidential candidates. The dummy for mixed-member systems is only statistically significant (at the 0.1 percent level) in the first model. The three additive models show that the fragmentation of presidential and legislative elections is more similar in presidential regimes than in semi-presidential ones. The dummy for presidential regimes is statistically significant in the first and third model at the 0.1 or 0.01 percent levels, respectively. When enep is the dependent variable (fifth model), there are no differences between presidential and semi-presidential regimes. The reason is that part of the effect of the dummy for presidential regimes is captured by enpres. Finally, the temporal proximity between presidential and legislative elections does not significantly affect the difference between enep and enpres.

Interestingly, the interaction between using a mixed-member system in legislative elections and the temporal proximity between presidential and legislative elections has the expected positive sign and is statistically significant at the 0.1 percent 
in two of the models (the second and the sixth): the less temporally proximate

presidential and legislative elections are, the greater the difference between enep and enpres when a mixed-member system is used in legislative elections. The effect of PR systems on party system fragmentation does not depend on the temporal proximity between presidential and legislative elections.

Table 1: The determinants of the difference between the effective number of electoral parties in legislative elections and the effective number of presidential candidates

\begin{tabular}{|c|c|c|c|c|c|c|}
\hline & $\begin{array}{c}\text { Enep-Enpres } \\
\text { (1) }\end{array}$ & $\begin{array}{c}\text { Enep-Enpres } \\
\text { (2) }\end{array}$ & $\begin{array}{c}\text { Log (Enep/Enpres) } \\
\text { (3) }\end{array}$ & $\begin{array}{c}\text { Log (Enep/Enpres) } \\
(4)\end{array}$ & $\begin{array}{l}\text { Enep } \\
(5)\end{array}$ & $\begin{array}{l}\text { Enep } \\
(6)\end{array}$ \\
\hline \multicolumn{7}{|l|}{$\begin{array}{l}\text { Legislative electoral system } \\
\text { (ref. Majoritarian) }\end{array}$} \\
\hline PR & $\begin{array}{l}1.384 * * * \\
(0.434)\end{array}$ & $\begin{array}{l}1.324 * \\
(0.696)\end{array}$ & $\begin{array}{l}0.291 * * \\
(0.136)\end{array}$ & $\begin{array}{l}0.250 \\
(0.179)\end{array}$ & $\begin{array}{l}1.347 * * * \\
(0.429)\end{array}$ & $\begin{array}{l}1.366^{*} \\
(0.694)\end{array}$ \\
\hline Mixed & $\begin{array}{l}0.768^{*} \\
(0.449)\end{array}$ & $\begin{array}{l}-0.114 \\
(0.390)\end{array}$ & $\begin{array}{c}0.160 \\
(0.177)\end{array}$ & $\begin{array}{l}-0.085 \\
(0.161)\end{array}$ & $\begin{array}{c}0.656 \\
(0.404)\end{array}$ & $\begin{array}{l}-0.161 \\
(0.370)\end{array}$ \\
\hline (log) Number of Days & $\begin{array}{c}-0.055 \\
(0.088)\end{array}$ & $\begin{array}{l}-0.124 \\
(0.075)\end{array}$ & $\begin{array}{c}0.002 \\
(0.022)\end{array}$ & $\begin{array}{l}-0.019 \\
(0.041)\end{array}$ & $\begin{array}{l}-0.059 \\
(0.087)\end{array}$ & $\begin{array}{l}-0.108 \\
(0.066)\end{array}$ \\
\hline Presidential regime & $\begin{array}{c}-0.945^{*} \\
(0.551)\end{array}$ & $\begin{array}{c}-0.927 * \\
(0.540)\end{array}$ & $\begin{array}{c}-0.419 * * * \\
(0.137)\end{array}$ & $\begin{array}{c}-0.419 * * * \\
(0.134)\end{array}$ & $\begin{array}{c}-0.691 \\
(0.516)\end{array}$ & $\begin{array}{l}-0.669 \\
(0.491)\end{array}$ \\
\hline PR * (log) Number of Days & & $\begin{array}{c}0.027 \\
(0.130)\end{array}$ & & $\begin{array}{c}0.012 \\
(0.049)\end{array}$ & & $\begin{array}{c}0.003 \\
(0.130)\end{array}$ \\
\hline Mixed $*(\log )$ Number of Days & & $\begin{array}{l}0.238^{*} \\
(0.129)\end{array}$ & & $\begin{array}{c}0.064 \\
(0.058)\end{array}$ & & $\begin{array}{l}0.218^{*} \\
(0.114)\end{array}$ \\
\hline Enpres & & & & & $\begin{array}{c}0.738 * * * \\
(0.228)\end{array}$ & $\begin{array}{c}0.739 * * * \\
(0.229)\end{array}$ \\
\hline Constant & $\begin{array}{c}0.861 \\
(0.546)\end{array}$ & $\begin{array}{c}1.071 * * \\
(0.480)\end{array}$ & $\begin{array}{c}0.375^{* *} \\
(0.168)\end{array}$ & $\begin{array}{c}0.450 * * \\
(0.168)\end{array}$ & $\begin{array}{l}1.528^{*} \\
(0.881)\end{array}$ & $\begin{array}{c}1.700 * * \\
(0.790)\end{array}$ \\
\hline $\mathrm{N}$ & 43 & 43 & 45 & 45 & 43 & 43 \\
\hline $\mathrm{R}^{2}$ & 0.178 & 0.206 & 0.263 & 0.286 & 0.309 & 0.333 \\
\hline
\end{tabular}

Note: Estimation is by OLS. Robust standard errors are in parentheses. ${ }^{*} \mathrm{p}<0.10 ; * * \mathrm{p}<0.05 ; * * * \mathrm{p}<0.01$ (two-tailed).

Electoral system scholarship establishes that the psychological effect of electoral systems takes at least two elections to manifest itself or at least that it is weak in the first election. However, to the best of my knowledge, this assumption has been never tested. When comparing the first presidential and legislative elections in third- and fourth-wave presidential and semi-presidential regimes, I have found that the effective number of electoral parties is greater than the effective number of presidential candidates when the 
electoral system employed in legislative elections is more permissive than in presidential elections. Both the mechanical and the psychological effects of electoral systems are then proximal. Finally, in order to know how much of the total amount of the psychological effect is already observed in first elections, longitudinal analyses are crucial. As here I am only considering the first presidential and legislative elections, I have shown that there is a meaningful psychological effect from the very beginning, but it not possible to determine whether this is the tip of the iceberg or most of it.

\section{References}

Andrews, Josephine T., and Robert W Jackman. 2005. "Strategic Fools: Electoral Rule Choice Under Extreme Uncertainty.” Electoral Studies 24: 65-84.

Best, Robin E. 2010. "Increasing Irrationality? The Equilibrium Relationship between Electoral and Legislative Party System Size.” Electoral Studies 29: 105-116.

Bielasiak, Jack. 2002. "The Institutionalization of Party Systems in Postcommunist States." Comparative Politics 34: 189-210.

Blais, André, and R. K. Carty. 1991. "The Psychological Impact of Electoral Laws: Measuring Duverger's Elusive Factor.” British Journal of Political Science 21: 79-93. Blais, André, Romain Lachat, Airo Hino, and Pascal Dorey-Demers. 2011. "The Mechanical and Psychological Effects of Electoral Systems: A Quasi-Experimental Study." Comparative Political Studies 44: 1599-1621.

Bormann, Nils-Christian, and Matt Golder. 2013 "Democratic Electoral Systems around the World, 1946-2011.” Electoral Studies 32: 360-369.

Cox, Gary W. 1997. Making Votes Count. Strategic Coordination in the World's Electoral Systems. New York: Cambridge University Press. 
Cheibub, José Antonio, Jennifer Gandhi, and James Raymond Vreeland. 2010.

“Democracy and Dictatorship Revisited." Public Choice 143: 67-101.

Crisp, Brian F., Santiago Olivella, and Joshua D. Potter. 2012. "Characteristics of

Electoral Contexts that Impede Voter Coordination.” Electoral Studies 31: 143-158.

Duch, Rayomd M., and Harvey D. Palmer. 2002. "Strategic Voting in Post-Communist

Democracy?” British Journal of Political Science 32: 63-91.

Duverger, Maurice. 1951. Les parties politiques [Political Parties]. Paris: Seuil.

Gallego, Aina, Guillem Rico, and Eva Anduiza. 2012. "Disproportionality and voter turnout in new and old democracies." Electoral Studies 31: 159-169.

Golder, Matt. 2006. "Presidential Coattails and Legislative Fragmentation.” American Journal of Political Science 50: 34-48.

Hicken, Allen, and Heather Stoll 2011. "Presidents and Parties: How Presidential Elections Shape Coordination in Legislative Elections." Comparative Political Studies 44: 854-83.

Lago, Ignacio, and Ferran Martínez. 2012. "Forgetting to make votes count: the role of previous democratic experience.” Electoral Studies 31: 413-421.

Mainwaring, Scott, and Edurne Zoco. 2007. "Political Sequences and the Stabilization of Interparty Competition: Electoral Volatility in Old and New Democracies." Party Politics 13: 155-178.

Rae, Douglas W. 1971. The Political Consequences of Electoral Laws. 2d ed. New Haven: Yale University Press.

Stoll, Heather. 2015. "Presidential coattails: A closer look.” Party Politics 21: 417-427. Taagepera, Rein, and Matthew Shugart. 1989. Seats and votes. The effects and determinants of electoral systems. Yale University Press, New Haven. 
Tavits, Margit. 2007. "Party Systems in the Making: The Emergence and Success of New Parties in New Democracies.” British Journal of Political Science 38: 113-133. Tavits, Margit, and Taavi Annus. 2006. "Learning to Make Votes Count: The Role of Democratic Experience.” Electoral Studies 25: 72-90. 


\section{APPENDIX}

\begin{tabular}{|c|c|c|c|c|c|c|c|}
\hline Country & Date leg. elec. & Legislative elec. syst. & enep & Date pres. elec. & enpres & Presidential regime & \# of days \\
\hline ARG & 1983-10-30 & $\mathrm{PR}$ & 2.63 & $1983-10-30$ & 2.3 & Presidential & 0 \\
\hline ARM & 1995-07-05 & Mixed & 4.18 & 1991-10-16 & 1.39 & Semi-presidential & 1358 \\
\hline BEN & 1991-02-17 & PR & 9.62 & 1991-03-10 & 4.29 & Presidential & 21 \\
\hline $\mathrm{BOL}$ & 1979-07-01 & PR & 3.5 & 1979-07-01 & 3.5 & Presidential & 0 \\
\hline$\overline{\text { BRA }}$ & 1986-11-15 & PR & 3.55 & 1989-11-15 & 5.69 & Presidential & 1096 \\
\hline BUI & 1993-06-29 & PR & 1.74 & 1993-06-01 & 1.85 & Presidential & 28 \\
\hline BUL & 1991-10-13 & PR & 4.12 & 1992-01-12 & 3.11 & Semi-presidential & 415 \\
\hline CAP & 1991-01-13 & PR & 1.81 & 1991-02-17 & 1.64 & Semi-presidential & 30 \\
\hline $\mathrm{CHL}$ & 1993-12-11 & PR & 6.55 & $1993-12-11$ & 2.47 & Presidential & 0 \\
\hline $\mathrm{COM}$ & 1992-11-22 & Majoritarian & 14.89 & 1990-02-18 & 6.12 & Semi-presidential & 1008 \\
\hline CRO & 1992-08-02 & Mixed & 4.19 & 1992-08-02 & 2.64 & Semi-presidential & 0 \\
\hline CYP & 1985-12-08 & PR & 3.62 & 1983-02-13 & 2.26 & Semi-presidential & 1029 \\
\hline ECU & 1979-04-29 & PR & 6.4 & 1979-04-29 & 4.76 & Presidential & 0 \\
\hline ETM & $2007-06-30$ & PR & 5.4 & $2002-04-14$ & 1.4 & Semi-presidential & 1903 \\
\hline GHA & 1979-06-18 & Majoritarian & 3.75 & 1979-06-18 & 3.92 & Presidential & 0 \\
\hline GRG & 2004-03-28 & Mixed & 1.91 & 2004-01-04 & 1.08 & Semi-presidential & 84 \\
\hline GUA & 1990-11-11 & PR & 7.01 & 1990-11-11 & 5.27 & Presidential & 0 \\
\hline $\mathrm{HON}$ & 1985-11-24 & PR & 2.14 & 1985-11-24 & 2.14 & Presidential & 0 \\
\hline INS & 1999-06-07 & PR & 5.05 & $2004-07-05$ & 3.94 & Presidential & 1855 \\
\hline KOR & $1988-04-26$ & Mixed & 4.23 & $1992-12-18$ & 1.77 & Presidential & 1697 \\
\hline KYR & $2007-12-16$ & $\mathrm{PR}$ & 4.43 & $2005-07-10$ & 1.26 & Semi-presidential & 889 \\
\hline LIT & 1992-10-25 & Mixed & 4.58 & 1993-02-14 & 1.97 & Semi-presidential & 112 \\
\hline MAC & 1994-10-16 & Majoritarian & 3.2 & 1994-10-16 & 1.51 & Semi-presidential & 0 \\
\hline MAD & 2009-05-09 & Majoritarian & 3.74 & $2008-10-08$ & 3.63 & Presidential & 213 \\
\hline MAW & 1994-05-17 & Majoritarian & 2.74 & $1994-05-17$ & 2.7 & Presidential & 0 \\
\hline MEX & 2000-07-02 & Mixed & 3 & $2000-07-02$ & 2.83 & Presidential & 0 \\
\hline MLD & 1998-03-22 & PR & 5.73 & 1996-11-17 & 3.92 & Parliamentary & 490 \\
\hline MLI & 1992-02-23 & Majoritarian & 3.56 & 1992-04-12 & 3.88 & Semi-presidential & 49 \\
\hline MON & 1992-06-28 & Majoritarian & 2.71 & 1993-06-06 & 1.92 & Semi-presidential & 343 \\
\hline NIC & $1990-02-25$ & PR & 2.18 & 1984-11-04 & 2.08 & Presidential & 1939 \\
\hline NIG & 1979-07-07 & Majoritarian & 3.71 & 1979-08-11 & 4.03 & Presidential & 35 \\
\hline NIR & 1993-02-14 & Mixed & 4.62 & 1993-02-27 & 4.19 & Semi-presidential & 13 \\
\hline PAR & 1989-05-01 & Mixed & 1.68 & 1989-05-01 & 1.62 & Presidential & 0 \\
\hline PER & 1980-05-18 & PR & 4.16 & 1980-05-18 & 3.45 & Presidential & 0 \\
\hline POL & 1991-10-27 & PR & 13.86 & $1990-11-25$ & 3.85 & Semi-presidential & 334 \\
\hline POR & $1976-04-25$ & PR & 4 & $1976-06-27$ & 2.31 & Semi-presidential & 63 \\
\hline ROM & 1990-05-20 & PR & 2.21 & 1990-05-20 & 1.36 & Semi-presidential & 0 \\
\hline SAL & 1985-03-31 & PR & 2.68 & 1984-03-25 & 3.16 & Presidential & 371 \\
\hline SEN & 2001-04-29 & Mixed & 3.27 & $2000-02-27$ & 3.33 & Semi-presidential & 427 \\
\hline SIE & 1996-02-27 & $\mathrm{PR}$ & 4.55 & 1996-02-27 & 4.64 & Presidential & 0 \\
\hline SLO & 1994-09-30 & PR & 5.81 & 1999-05-15 & 2.71 & Semi-presidential & 1688 \\
\hline SLV & 1992-12-06 & $\mathrm{PR}$ & 8.34 & 1992-12-06 & 2.14 & Semi-presidential & 0 \\
\hline SRI & 1989-02-15 & PR & 2.74 & 1994-11-09 & 1.93 & Presidential & 2093 \\
\hline STP & 1991-01-20 & PR & 2.51 & 1991-03-03 & 1 & Semi-presidential & 42 \\
\hline TAW & 1998-12-05 & Mixed & 3.14 & 1996-03-23 & 2.71 & Semi-presidential & 987 \\
\hline UKR & 1994-03-27 & Majoritarian & 2.16 & 1991-12-01 & 2.28 & Semi-presidential & 847 \\
\hline YUG & $2000-09-24$ & PR & 3.11 & $2000-09-24$ & 2.39 & Semi-presidential & 0 \\
\hline
\end{tabular}

